\title{
[Regular Paper] \\ Effect of Chemical and Physical Properties of Titanium Oxide Support Surface during Nitrogen Monoxide Reduction by Carbon Monoxide in Presence Water over Titanium Oxide Supported Platinum Catalyst
}

\author{
Keisuke KobaYAShI $^{\dagger 1), \dagger 2) *}$, Shotaro OGaWA ${ }^{\dagger 3)}$, Hideyuki Matsumoto ${ }^{\dagger 2), \dagger 3), ~}$ \\ Keigo MATSUDA ${ }^{\dagger 1), \dagger 2)}$, and Tetsuya NANBA ${ }^{\dagger 2}$ \\ ${ }^{\dagger 1)}$ Dept. of Chemistry and Chemical Engineering, Graduate School of Science and Engineering, Yamagata University, \\ 4-3-16 Johnan, Yonezawa, Yamagata 992-8510, JAPAN \\ ${ }^{\dagger 2}$ Renewable Energy Research Center, National Institute of Advanced Industrial Science and Technology (AIST), \\ 2-2-9 Machiikedai, Koriyama, Fukushima 963-0298, JAPAN \\ ${ }^{\dagger 3}$ Dept. of Chemical Science and Engineering, Tokyo Institute of Technology, \\ 2-12-1 Ookayama, Meguro-ku, Tokyo 152-8550, JAPAN
}

(Received September 18, 2019)

\begin{abstract}
With the goal of developing a method for utilizing reactive nitrogen species emitted from combustion processes as raw materials for the synthesis of useful compounds, we investigated the selective conversion of $\mathrm{NO}_{x}$ to $\mathrm{NH}_{3}$ by means of the $\mathrm{NO}-\mathrm{CO}-\mathrm{H}_{2} \mathrm{O}$ reaction over $\mathrm{Pt} / \mathrm{TiO}_{2}$ catalysts. High $\mathrm{NH}_{3}$ selectivity was obtained for high-specific-surface-area catalysts. Catalytic activity tests revealed that the activities of catalysts depended on the crystal structure of the support. Comparing $\mathrm{CO}$ conversion between $\mathrm{NO}-\mathrm{CO}-\mathrm{H}_{2} \mathrm{O}$ reaction and $\mathrm{CO}-\mathrm{H}_{2} \mathrm{O}$ reaction, which could play a role of $\mathrm{H}$-supply reaction, $\mathrm{Pt} / \mathrm{TiO}_{2}$ exhibited higher $\mathrm{CO}$ conversion for the $\mathrm{NO}-\mathrm{CO}-\mathrm{H}_{2} \mathrm{O}$ reaction than that for $\mathrm{CO}-\mathrm{H}_{2} \mathrm{O}$ reaction except for high-surface-area anatase $\mathrm{TiO}_{2}$-supported catalyst around $200{ }^{\circ} \mathrm{C}$. We focused on how the chemical and physical properties of the catalyst surface. Specifically, we carried out temperature-programmed desorption of $\mathrm{CO}_{2}$, which revealed that the $\mathrm{CO}_{2}$ formed during the $\mathrm{NO}-\mathrm{CO}-\mathrm{H}_{2} \mathrm{O}$ reaction had no effect on the difference in activity. Carbonaceous surface species and $\mathrm{NH}_{x}$ species were observed on the surface of $\mathrm{Pt} / \mathrm{TiO}_{2}$ catalyst during $\mathrm{NO}-\mathrm{CO}-\mathrm{H}_{2} \mathrm{O}$ reaction by diffused reflectance infrared Fourier transform spectroscopy, and difference in formate formation on anatase- $\mathrm{TiO}_{2}$ supported Pt catalyst was confirmed compared to rutile- $\mathrm{TiO}_{2}$ supported $\mathrm{Pt}$ catalyst. We supposed that the difference in activity between anatase and rutile $\mathrm{TiO}_{2}$ was caused by behavior of formate formation.
\end{abstract}

\section{Keywords}

Platinum catalyst, Titanium oxide support, Nitrogen oxide, Ammonia

\section{Introduction}

Reactive nitrogen $(\mathrm{Nr})$ species, such as $\mathrm{NO}, \mathrm{NO}_{2}$, $\mathrm{NO}^{3-}$, and $\mathrm{NO}^{2-}$, are harmful chemicals that cause environmental pollution (photochemical smog and acid rain) and have deleterious effects on human health. The environmental capacity for these $\mathrm{Nr}$ species has been estimated to be already overflowed in the world ${ }^{1)}$. Therefore, it is argent issue to optimize and control the nitrogen circulation in the nature.

Nitrogen oxides $\left(\mathrm{NO}_{x}\right)$ are mainly emitted by vehicles and the thermal power plant using fossil fuels like coal, petroleum, natural gas ${ }^{2}$. Methods for reducing $\mathrm{NO}_{x}$ emissions include $\mathrm{NO}_{x}$ storage/reduction, lean $\mathrm{NO}_{x}$

DOI: doi.org/10.1627/jpi.63.28

* To whom correspondence should be addressed.

* E-mail: kobayashi.keisuke@ aist.go.jp traps, and selective catalytic reduction; and the literature on these methods is vast ${ }^{3) \sim 8)}$. A major $\operatorname{deNO}_{x}$ technic is by $\mathrm{NH}_{3}$, whereby $\mathrm{NO}_{x}$ is reduced to $\mathrm{N}_{2}$ by $\mathrm{NH}_{3}$ :

$$
4 \mathrm{NO}+4 \mathrm{NH}_{3}+\mathrm{O}_{2} \rightarrow 4 \mathrm{~N}_{2}+6 \mathrm{H}_{2} \mathrm{O}
$$

The standard heat of formation of $\mathrm{NO}$ is $-90 \mathrm{~kJ}$ $\mathrm{mol}^{-1}$, and the standard heat of combustion of $\mathrm{NH}_{3}$ is $383 \mathrm{~kJ} \mathrm{~mol}^{-1}$. The excess energy compensates for the internal energy of NO. NO (bond energy, $632 \mathrm{~kJ} \mathrm{~mol}^{-1}$ ) has much higher reactivity than $\mathrm{N}_{2}\left(945 \mathrm{~kJ} \mathrm{~mol}^{-1}\right)$ and can therefore be easily converted to other nitrogencontaining compounds. However, because $\mathrm{NH}_{3}$ is not only a useful raw material for the synthesis of various kinds of chemicals but also an energy carrier $^{9), 10)}$, we have been studying catalysts for $\mathrm{NO}$ conversion to $\mathrm{NH}_{3}$. We recently proposed a concept, designated $\operatorname{recNO}_{x}$, for recovery of $\mathrm{NO}_{x}$ as the energy carrier ${ }^{11)}$. If $\mathrm{NO}_{x}$ can 
Table 1 Activity Test Conditions

\begin{tabular}{lccccc}
\hline \multicolumn{1}{c}{ Reaction } & Balance gas & $\mathrm{NO}[\%]$ & $\mathrm{CO}[\%]$ & $\mathrm{H}_{2} \mathrm{O}[\%]$ & $\mathrm{CO}_{2}[\%]$ \\
\hline $\mathrm{NO}-\mathrm{CO}-\mathrm{H}_{2} \mathrm{O}$ & $\mathrm{Ar}$ & 0.1 & 0.3 & 1 & - \\
$\mathrm{CO}-\mathrm{H}_{2} \mathrm{O}$ & $\mathrm{Ar}$ & - & 0.3 & 1 & - \\
$\mathrm{NO}-\mathrm{CO}-\mathrm{H}_{2} \mathrm{O}-\mathrm{CO}_{2}$ & $\mathrm{Ar}$ & 0.1 & 0.3 & 1 & 1 \\
\hline
\end{tabular}

be converted to useful substances such as $\mathrm{NH}_{3}$, then a higher concentration of $\mathrm{NO}_{x}$ in combustion exhaust gases is actually preferable; and combustors can be operated under the most efficient conditions without the need to be concerned about NO suppression. Therefore, implementation of recNO $\mathrm{N}_{x}$ systems can be expected to considerably decrease $\mathrm{CO}_{2}$ emissions.

There are two ways to generate $\mathrm{NH}_{3}$ from $\mathrm{NO}_{x}$ : the NO- $\mathrm{H}_{2}$ reaction $\left(2 \mathrm{NO}+5 \mathrm{H}_{2} \rightarrow 2 \mathrm{NH}_{3}+2 \mathrm{H}_{2} \mathrm{O}\right)$ and the $\mathrm{NO}-\mathrm{CO}-\mathrm{H}_{2} \mathrm{O}$ reaction $\left(2 \mathrm{NO}+5 \mathrm{CO}+3 \mathrm{H}_{2} \mathrm{O} \rightarrow 2 \mathrm{NH}_{3}+\right.$ $\left.5 \mathrm{CO}_{2}\right)^{12) \sim 16)}$. Although the $\mathrm{NO}-\mathrm{H}_{2}$ reaction proceeds at temperatures as low as $100{ }^{\circ} \mathrm{C}$, forming $\mathrm{NH}_{3}$ with high selectivity is difficult under stoichiometric conditions ${ }^{16), 17)}$, and high $\mathrm{NH}_{3}$ selectivity is necessary for efficient recovery of $\mathrm{NO}_{x}$. We previously reported that a $\mathrm{Pt} / \mathrm{TiO}_{2}$-catalyzed NO-CO- $\mathrm{H}_{2} \mathrm{O}$ reaction shows high $\mathrm{NH}_{3}$ selectivity in the temperature range from 100 to $300{ }^{\circ} \mathrm{C}^{11), 18)}$. We investigated the effects of the crystal structure of the $\mathrm{TiO}_{2}$ support on the catalyst activity, and we estimated the kinetic parameters of the reaction ${ }^{11)}$. The specific surface area of anatase $\mathrm{TiO}_{2}$ is larger than that of rutile $\mathrm{TiO}_{2}$ because the rutile phase is generated at higher temperatures and therefore has relatively large crystallites ${ }^{19)}$ 21). In our previous study, we evaluated the effects of the crystal structure of $\mathrm{TiO}_{2}$ supports with different surface areas ${ }^{11}$, but to more accurately determine crystal structure effects, samples with similar specific surface areas must be evaluated.

In this study, we evaluated the activities of Pt catalysts supported on anatase and rutile $\mathrm{TiO}_{2}$ with relatively high and low specific surface area. We determined the physical and chemical properties of the $\mathrm{Pt} / \mathrm{TiO}_{2}$ catalysts, and we discuss the mechanism of the $\mathrm{NO}^{-} \mathrm{CO}^{-}$ $\mathrm{H}_{2} \mathrm{O}$ reaction over these catalysts.

\section{Experimental}

\section{1. Catalyst Preparation}

$\mathrm{TiO}_{2}$-supported platinum catalysts were prepared by means of an incipient wetness method. Four different $\mathrm{TiO}_{2}$ supports were used: $\mathrm{TiO}_{2}(\mathrm{~A}) \mathrm{H}$ (SSP-M, Sakai Chemical Industry Co.; $\mathrm{A}=$ anatase, $\mathrm{H}=$ high specific surface area), $\mathrm{TiO}_{2}(\mathrm{~A}) \mathrm{L}$ (Wako Pure Chem. Ind., Ltd.; $\mathrm{L}=$ low specific surface area), $\mathrm{TiO}_{2}(\mathrm{R}) \mathrm{H}(\mathrm{STR}-100 \mathrm{~N}$, Sakai Chemical Industry Co.; $\mathrm{R}=$ rutile), and $\mathrm{TiO}_{2}(\mathrm{R}) \mathrm{L}$, which was prepared by calcination of $\mathrm{TiO}_{2}(\mathrm{R}) \mathrm{H}$ at $900{ }^{\circ} \mathrm{C}$ for $6 \mathrm{~h} . \mathrm{H}_{2} \mathrm{PtCl}_{6}$ (Wako Pure Chem. Ind., Ltd.) was used as a Pt precursor and was diluted to the desired concentration with deionized water. The pow- dered $\mathrm{TiO}_{2}$ supports were immersed in the aqueous $\mathrm{Pt}$ solution, and the resulting suspensions were allowed to stand for $30 \mathrm{~min}$ and then dried at $100{ }^{\circ} \mathrm{C}$ overnight in a drier. The dried samples were calcined at $500{ }^{\circ} \mathrm{C}$ for $4 \mathrm{~h}$ in air and then reduced with $10 \mathrm{vol}^{\circ} \mathrm{H}_{2}$ in $\mathrm{N}_{2}$ as a balance gas at $400{ }^{\circ} \mathrm{C}$ for $1 \mathrm{~h}$. This procedure yielded $1 \mathrm{wt} \% \mathrm{Pt} / \mathrm{TiO}_{2}$ catalysts, which were sieved to 250 $150 \mu \mathrm{m}$ for activity testing and characterization.

\section{2. Activity Test}

Activity tests were performed in a fixed-bed flow reactor. Catalyst $(150 \mathrm{mg})$ was placed in a quartz reactor with an outer diameter of $10 \mathrm{~mm}$, and quartz glass wool was placed in the middle of the reactor. The reaction conditions for the activity tests are shown in Table 1; the total gas flow rate was set at $250 \mathrm{~mL}$ $\mathrm{min}^{-1}$. Product gases were analyzed by means of Fourier transform IR spectroscopy in a multireflection gas cell (optical path length, $2.4 \mathrm{~m}$ ) and by gas chromatography (3000 Micro GC, INFICON). NO conversion, $\mathrm{CO}$ conversion, and $\mathrm{NO}$ conversion to $\mathrm{NH}_{3}$ were calculated by means of the following equations:

$$
\begin{aligned}
& \mathrm{NO} \text { conversion }(\%)=\left(\mathrm{NO}_{\text {in }}-\mathrm{NO}_{\text {out }}\right) / \mathrm{NO}_{\text {in }} \times 100 \\
& \mathrm{CO} \text { conversion }(\%)=\left(\mathrm{CO}_{\text {in }}-\mathrm{CO}_{\text {out }}\right) / \mathrm{CO}_{\text {in }} \times 100 \\
& \mathrm{CO} \text { conversion to } \mathrm{NH}_{3}(\%)= \\
& \mathrm{NH}_{3 \text { out }} /\left(\mathrm{NH}_{3 \text { out }}+2 \mathrm{~N}_{2 \text { out }}+2 \mathrm{~N}_{2} \mathrm{O}_{\text {out }}\right)
\end{aligned}
$$

Reaction orders were calculated by means of a powerlaw rate equation:

$$
r=k P_{\mathrm{NO}}^{l} P_{\mathrm{CO}}^{m} P_{\mathrm{H}_{2} \mathrm{O}}^{n}
$$

where $r$ is rate of the $\mathrm{NH}_{3}$ synthesis reaction (in mol $\left.\mathrm{g}^{-1} \mathrm{~h}^{-1}\right) ; k$ is the rate constant; and $l, m$, and $n$ are the reaction orders with respect to $\mathrm{NO}, \mathrm{CO}$ and $\mathrm{H}_{2} \mathrm{O}$, respectively. Additional details regarding experimental conditions are described in a previous paper ${ }^{11)}$.

\section{3. Characterizations}

The crystal structures of the catalysts and supports were determined by X-ray diffraction analysis (SmartLab, Rigaku Corp.) under the following conditions: scan speed, $0.2^{\circ}$; scan step, $1.0^{\circ}$; and $2 \theta$ range, $20-60^{\circ}$ ). The crystallite sizes of the $\mathrm{TiO}_{2}$ supports were estimated by means of the Scherrer equation. $\mathrm{N}_{2}$ adsorptiondesorption isotherms were measured at $-196{ }^{\circ} \mathrm{C}$ (BELSORP-mini II, MicrotracBEL Corp.). Specific surface areas and pore size distributions were calculated by means of the Brunauer-Emmett-Teller equation and the Barrett-Joyner-Halenda method, respectively.

Platinum dispersions were calculated by means of 

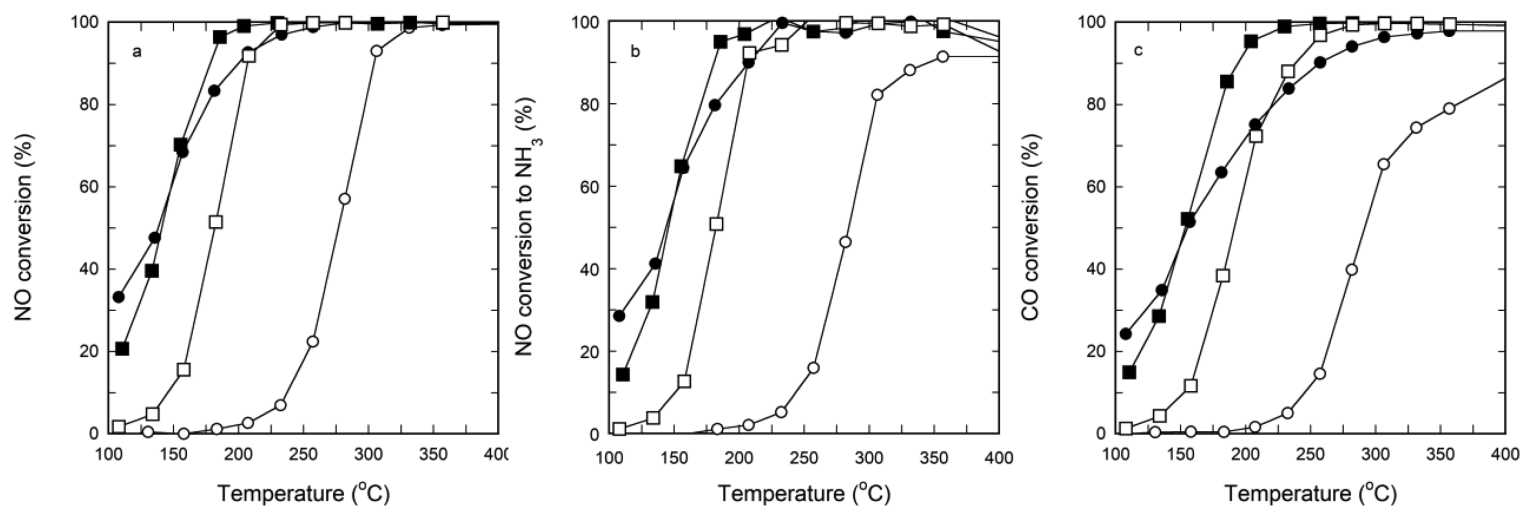

Reaction mixture: $0.1 \% \mathrm{NO}, 0.3 \% \mathrm{CO}, 1 \% \mathrm{H}_{2} \mathrm{O}$ in argon as the balance gas.

Fig. 1 Temperature Dependence of (a) NO Conversion, (b) NO Conversion to $\mathrm{NH}_{3}$, and (c) $\mathrm{CO} \mathrm{Conversion} \mathrm{for} \mathrm{Pt} / \mathrm{TiO} 2(\mathrm{~A}) \mathrm{H}(\mathbf{O}), \mathrm{Pt} /$ $\mathrm{TiO}_{2}(\mathrm{~A}) \mathrm{L}(\mathrm{O}), \mathrm{Pt} / \mathrm{TiO}_{2}(\mathrm{R}) \mathrm{H}(\square)$, and $\mathrm{Pt} / \mathrm{TiO}_{2}(\mathrm{R}) \mathrm{L}(\square)$

CO pulse adsorption (BEL-METAL-3, MicrotracBEL Corp.). Catalyst samples were oxidized with $\mathrm{O}_{2}$ $(99.9999 \%)$ at $400{ }^{\circ} \mathrm{C}$ for $20 \mathrm{~min}$ and then reduced with $\mathrm{H}_{2}(99.9999 \%)$ at $400{ }^{\circ} \mathrm{C}$ for $20 \mathrm{~min}$. The distributions of Pt particle sizes were estimated by transmission electron microscopy (TEM) analysis (JEM-2100F, JEOL Ltd.); the sizes were estimated to be in the range between $0 \mathrm{~nm}$ and $3.2 \mathrm{~nm}$.

Temperature-programmed reduction by hydrogen $\left(\mathrm{H}_{2}\right.$-TPR) was carried out as follows. Each catalyst sample $(150 \mathrm{mg})$ was placed in a quartz tube, and measurements were performed with a Cyrocat (MicrotracBEL Corp.). The samples were pretreated by oxidation at $500{ }^{\circ} \mathrm{C}$ for $1 \mathrm{~h}$, cooled to $-70{ }^{\circ} \mathrm{C}$, and then treated with $\mathrm{H}_{2}\left(1 \mathrm{vol} \%\right.$ in helium, $\left.50 \mathrm{~mL} \mathrm{~min}^{-1}\right)$ at $-70{ }^{\circ} \mathrm{C}$. The effluent gas was analyzed by time of flight mass spectrometry (JMS-MT3010HRGA, JEOL Ltd.). After the signal for $\mathrm{H}_{2}$ at $\mathrm{m} / z 2$ stabilized, the samples were heated to $800{ }^{\circ} \mathrm{C}\left(10{ }^{\circ} \mathrm{C} \mathrm{min}{ }^{-1}\right)$.

Temperature-programmed desorption of $\mathrm{CO}_{2}\left(\mathrm{CO}_{2-}\right.$ TPD) was carried out in a flow reactor system equipped with a quadrupole mass spectrometer (Microvision, Spectra Co.). Each sample (150 mg) was placed in the quartz reactor used for the activity tests and reduced at $400{ }^{\circ} \mathrm{C}$ for 30 min with $\mathrm{H}_{2}$ (10 vol\% in helium). Next, the sample was purged with helium gas at $400{ }^{\circ} \mathrm{C}$ for 30 min and cooled to room temperature. The sample was then treated with a flow of $\mathrm{CO}_{2}(10 \mathrm{vol} \%$ in helium $)$ until saturation of the mass signal for $\mathrm{CO}_{2}$ at $\mathrm{m} / \mathrm{z} 44$. Finally, the sample was purged with helium for $30 \mathrm{~min}$ and then heated to $500{ }^{\circ} \mathrm{C}$ (at $10{ }^{\circ} \mathrm{C} \mathrm{min}-1$ ) while the signal at $\mathrm{m} / \mathrm{z} 44$ was monitored.

Diffuse reflectance infrared Fourier transform spectroscopy (DRIFTS) measurement was carried out with an iS50 spectrometer (Thermo Fisher Scientific K. K.) equipped with a DRIFT cell. Each catalyst was placed in the cell of Heat Chamber Type- $1000{ }^{\circ} \mathrm{C}$ (S. T. Japan Inc.) and reduced under $\mathrm{H}_{2}$ at $400{ }^{\circ} \mathrm{C}$ for $30 \mathrm{~min}$, cooled to room temperature, and then exposed to a flow of $0.3 \% \mathrm{CO}$ and $0.5 \% \mathrm{H}_{2} \mathrm{O}$ (bubbling at $10{ }^{\circ} \mathrm{C}$ ) with and without $0.1 \% \mathrm{NO}$ in He. Total gas flow was $30 \mathrm{~mL}$ $\min ^{-1}$. Background was measured under $\mathrm{He}$ in the presence $0.5 \% \mathrm{H}_{2} \mathrm{O}$. The spectra of $\mathrm{Pt} / \mathrm{TiO}_{2}(\mathrm{~A}) \mathrm{H}$ and $\mathrm{Pt} / \mathrm{TiO}_{2}(\mathrm{R}) \mathrm{H}$ were measured at $150{ }^{\circ} \mathrm{C}$ and $200{ }^{\circ} \mathrm{C}$.

Temperature-programmed desorption of $\mathrm{NH}_{3}\left(\mathrm{NH}_{3}\right.$ TPD) was carried out in a flow reactor system equipped with a quadrupole mass spectrometer (Microvision, Spectra Co.). Each sample (100 mg) was placed in the quartz reactor used for the activity tests and reduced at $400{ }^{\circ} \mathrm{C}$ for 30 min with $\mathrm{H}_{2}$ (10 vol\% in argon). Next, the sample was purged with argon gas at $400{ }^{\circ} \mathrm{C}$ for $30 \mathrm{~min}$ and cooled to room temperature. The sample was then treated with a flow of $\mathrm{NH}_{3}(0.5 \mathrm{vol} \%$ in argon $)$ until saturation of the mass signal for $\mathrm{NH}_{3}$ at $m / z 17$. Finally, the sample was purged with argon for $1 \mathrm{~h}$ and then heated to $600{ }^{\circ} \mathrm{C}$ (at $10{ }^{\circ} \mathrm{C} \mathrm{min}{ }^{-1}$ ) while the signal at $m / z, 17$ was monitored.

\section{4. Catalytic Activities}

\section{4. 1. Activity Test}

The activities of the $\mathrm{Pt} / \mathrm{TiO}_{2}$ catalysts for the NOCO- $\mathrm{H}_{2} \mathrm{O}$ reaction were measured, and the results are shown in Fig. 1. The NO conversions at $110{ }^{\circ} \mathrm{C}$ for $\mathrm{Pt} / \mathrm{TiO}_{2}(\mathrm{~A}) \mathrm{H}$ and $\mathrm{Pt} / \mathrm{TiO}_{2}(\mathrm{R}) \mathrm{H}$ were $33 \%$ and $21 \%$, respectively, and the temperatures at which NO conversion reached $90 \%$ were $200{ }^{\circ} \mathrm{C}$ and $180{ }^{\circ} \mathrm{C}$ (Fig. 1a). That is, at low temperature, $\mathrm{Pt} / \mathrm{TiO}_{2}(\mathrm{~A}) \mathrm{H}$ exhibited higher $\mathrm{NO}$ conversion than $\mathrm{Pt} / \mathrm{TiO}_{2}(\mathrm{R}) \mathrm{H}$, but almost complete NO conversion was achieved at a lower temperature with $\mathrm{Pt} / \mathrm{TiO}_{2}(\mathrm{R}) \mathrm{H}$ than with $\mathrm{Pt} / \mathrm{TiO}_{2}(\mathrm{~A}) \mathrm{H}$. Over $\mathrm{Pt} / \mathrm{TiO}_{2}(\mathrm{~A}) \mathrm{L}$ and $\mathrm{Pt} / \mathrm{TiO}_{2}(\mathrm{R}) \mathrm{L}$, NO conversion was complete at temperatures above $325^{\circ} \mathrm{C}$ and $225^{\circ} \mathrm{C}$, respectively, and the temperatures at which NO conversion reached $10 \%$ were $225^{\circ} \mathrm{C}$ and $125{ }^{\circ} \mathrm{C}$ (Fig. 1a). The trends for $\mathrm{NO}$ conversion to $\mathrm{NH}_{3}$ were similar to those for NO conversion for all the catalysts except Pt/ $\mathrm{TiO}_{2}(\mathrm{~A}) \mathrm{L}$ (Fig. 1b); over this catalyst, the maximum 
NO conversion to $\mathrm{NH}_{3}$ was $90 \%$, whereas NO conversion reached almost $100 \%$. These results suggest that high $\mathrm{NH}_{3}$ selectivity was due mainly to high surface area, and that the effects of the crystal structure of the support were negligible. The trends in $\mathrm{CO}$ conversion for the catalysts were similar to those for NO conversion (Fig. 1c), because the $\mathrm{CO}$ concentration in the feed was slightly higher than the stoichiometric concentration.

The activities of $\mathrm{Pt} / \mathrm{TiO}_{2}$ catalysts for the $\mathrm{NO}-\mathrm{CO}$ reaction and $\mathrm{CO}-\mathrm{H}_{2} \mathrm{O}$ reaction were performed. $\mathrm{NH}_{3}$ formation were not confirmed during $\mathrm{NO}^{-} \mathrm{CO}$ reaction for all catalysts. The results of $\mathrm{CO}-\mathrm{H}_{2} \mathrm{O}$ reaction were shown in Fig. 2. CO conversion of $\mathrm{Pt} / \mathrm{TiO}_{2}(\mathrm{~A}) \mathrm{L}$ and $\mathrm{Pt} / \mathrm{TiO}_{2}(\mathrm{R}) \mathrm{L}$ were lower than that for the NO-CO- $\mathrm{H}_{2} \mathrm{O}$ reaction. Previously, we supposed that the $\mathrm{CO}-\mathrm{H}_{2} \mathrm{O}$ reaction could an origin of hydrogen supply for $\mathrm{NH}_{3}$ formation ${ }^{11)}$. For high-surface-area catalysts, $\mathrm{CO}$ conversion increased with increasing temperature, and then decreased along with the equilibrium line. $\mathrm{CO}$ conversion for $\mathrm{Pt} / \mathrm{TiO}_{2}(\mathrm{R}) \mathrm{H}$ was lower than that of the $\mathrm{NO}^{-}$ CO- $\mathrm{H}_{2} \mathrm{O}$ reaction as well as the low-surface area catalysts. On the contrary, $\mathrm{Pt} / \mathrm{TiO}_{2}(\mathrm{~A}) \mathrm{H}$ exhibited higher $\mathrm{CO}$ conversion that of the $\mathrm{NO}-\mathrm{CO}-\mathrm{H}_{2} \mathrm{O}$ reaction at around $200{ }^{\circ} \mathrm{C}$. It is noted that for $\mathrm{Pt} / \mathrm{TiO}_{2}(\mathrm{~A}) \mathrm{H}$ and $\mathrm{Pt} / \mathrm{TiO}_{2}(\mathrm{R}) \mathrm{H}, \mathrm{CO}$ conversion of that $\mathrm{NO}-\mathrm{CO}-\mathrm{H}_{2} \mathrm{O}$ reac-

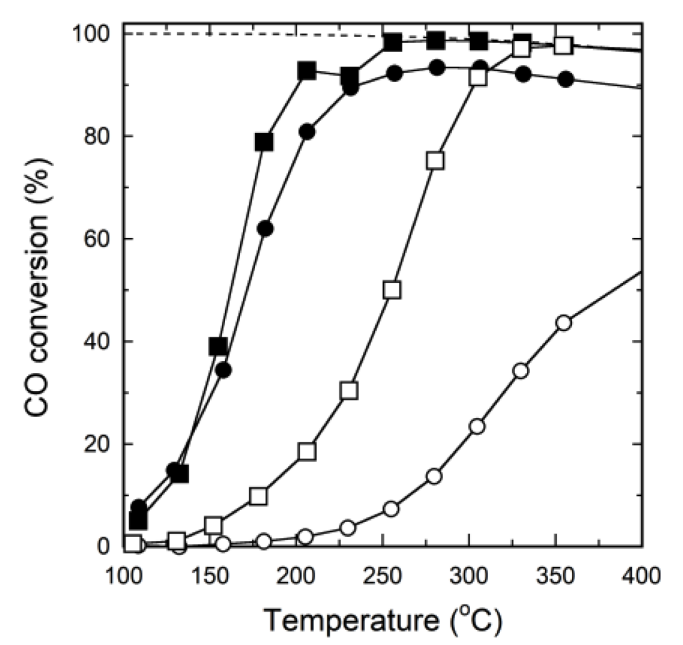

Reaction mixture: $0.3 \% \mathrm{CO}, 1 \% \mathrm{H}_{2} \mathrm{O}$ in argon as the balance gas.

Fig. 2 Temperature Dependence of CO Conversion for Pt/ $\mathrm{TiO}_{2}(\mathrm{~A}) \mathrm{H}(\bigcirc), \mathrm{Pt} / \mathrm{TiO}_{2}(\mathrm{~A}) \mathrm{L}(\bigcirc), \mathrm{Pt} / \mathrm{TiO}_{2}(\mathrm{R}) \mathrm{H}(\square), \mathrm{Pt} /$ $\mathrm{TiO}_{2}(\mathrm{R}) \mathrm{L}(\square)$ and Equilibrium Conversion (dashed line) tion exceeded the equilibrium of $\mathrm{CO}$ conversion. This behavior may be due to consumption of $\mathrm{H}_{2}$ formed from the $\mathrm{CO}-\mathrm{H}_{2} \mathrm{O}$ reaction by the reaction to form $\mathrm{NH}_{3}$. From these results, $\mathrm{Pt} / \mathrm{TiO}_{2}(\mathrm{~A}) \mathrm{H}$ showed different behavior of hydrogen supply from the $\mathrm{CO}-\mathrm{H}_{2} \mathrm{O}$ reaction.

\section{4. 2. Kinetic Measurements}

The reaction orders for the $\mathrm{NO}-\mathrm{CO}-\mathrm{H}_{2} \mathrm{O}$ reaction are listed in Table 2 for the four $\mathrm{Pt} / \mathrm{TiO}_{2}$ catalysts. In all cases, the order with respect to $\mathrm{NO}$ was positive. For $\mathrm{Pt} / \mathrm{TiO}_{2}(\mathrm{~A}) \mathrm{H}$ and $\mathrm{Pt} / \mathrm{TiO}_{2}(\mathrm{R}) \mathrm{H}$ the orders with respect to $\mathrm{CO}$ were close to zero, whereas for $\mathrm{Pt} / \mathrm{TiO}_{2}(\mathrm{~A}) \mathrm{L}$ and $\mathrm{Pt} / \mathrm{TiO}_{2}(\mathrm{R}) \mathrm{L}$, the orders were -0.47 and -0.54 , respectively. These results suggest that $\mathrm{CO}$ poisoning of the low-surface-area catalysts occurred regardless of the crystal structure of the support. The reaction orders with respect to $\mathrm{H}_{2} \mathrm{O}$ for $\mathrm{Pt} / \mathrm{TiO}_{2}(\mathrm{~A}) \mathrm{H}$ and $\mathrm{Pt} / \mathrm{TiO}_{2}(\mathrm{~A}) \mathrm{H}$ were positive, and those for $\mathrm{Pt} / \mathrm{TiO}_{2}(\mathrm{~A}) \mathrm{L}$ and $\mathrm{Pt}$ / $\mathrm{TiO}_{2}(\mathrm{R}) \mathrm{L}$ were close to zero. Previously, we reported that the reaction orders with respect to $\mathrm{CO}$ and $\mathrm{H}_{2} \mathrm{O}$ for $\mathrm{Pt} / \mathrm{TiO}_{2}(\mathrm{~A})$ differed from the corresponding values for $\mathrm{Pt} / \mathrm{TiO}_{2}(\mathrm{R}) \mathrm{L}^{11)}$. These results suggest that the differences between the reaction orders were due not to differences in crystal structure but to differences in surface area. In our previous report, we speculated that $\mathrm{H}_{2} \mathrm{O}$ adsorption on $\mathrm{TiO}_{2}$ and subsequent reaction are an important source of hydrogen to form $\mathrm{NH}_{3}{ }^{11)}$. If this is in fact the case, surface area would be the most important factor controlling the rate of $\mathrm{H}_{2} \mathrm{O}$ activation. That is, the number and/or the density of $\mathrm{H}_{2} \mathrm{O}$-activation sites on the $\mathrm{TiO}_{2}$ surface would strongly influence the rate of NO-CO- $\mathrm{H}_{2} \mathrm{O}$ reaction, independent of the crystal structure.

\section{5. Characterization of Physical Properties}

\section{5. 1. X-ray Diffraction and $N_{2}$ Adsorption}

To investigate the difference in activity, we attempted to elucidate differences in the physical properties of the $\mathrm{Pt} / \mathrm{TiO}_{2}$ catalysts. The X-ray diffraction (XRD) patterns of the catalysts and supports are shown in Fig. 3 . All the peaks in the patterns of $\mathrm{Pt} / \mathrm{TiO}_{2}(\mathrm{~A}) \mathrm{H}, \mathrm{TiO}_{2}(\mathrm{~A}) \mathrm{H}$, $\mathrm{Pt} / \mathrm{TiO}_{2}(\mathrm{R}) \mathrm{H}$, and $\mathrm{TiO}_{2}(\mathrm{R}) \mathrm{H}$ were broader than the peaks in the $\mathrm{Pt} / \mathrm{TiO}_{2}(\mathrm{~A}) \mathrm{L}, \mathrm{TiO}_{2}(\mathrm{~A}) \mathrm{L}, \mathrm{Pt} / \mathrm{TiO}_{2}(\mathrm{R}) \mathrm{L}$, and $\mathrm{TiO}_{2}(\mathrm{R}) \mathrm{L}$ patterns, suggesting that the samples with high specific surface area consisted of $\mathrm{TiO}_{2}$ with a small crystallite size. The $\mathrm{TiO}_{2}$ crystallite sizes, as calculated by means of the Scherrer equation, are listed in Table 3. The $\mathrm{Pt} / \mathrm{TiO}_{2}(\mathrm{~A}) \mathrm{H}$ and $\mathrm{Pt} / \mathrm{TiO}_{2}(\mathrm{R}) \mathrm{H}$ crystallite sizes were almost the same. The diffraction peak at $39.8^{\circ}$, which was assigned to metallic Pt, was ob-

Table 2 Reaction Orders with Respect to $\mathrm{NO}(l), \mathrm{CO}(m)$ and $\mathrm{H}_{2} \mathrm{O}(n)$ for the NO-CO- $\mathrm{H}_{2} \mathrm{O}$ Reaction

\begin{tabular}{cccccc}
\hline Catalyst & Temp. $\left[{ }^{\circ} \mathrm{C}\right]$ & $l$ & $m$ & $n$ & Report \\
\hline $\mathrm{Pt} / \mathrm{TiO}_{2}(\mathrm{~A}) \mathrm{H}$ & 125 & 0.34 & -0.06 & 0.39 & Ref. 11) \\
$\mathrm{Pt} / \mathrm{TiO}_{2}(\mathrm{~A}) \mathrm{L}$ & 200 & 0.27 & -0.46 & 0.06 & this report \\
$\mathrm{Pt} / \mathrm{TiO}_{2}(\mathrm{R}) \mathrm{H}$ & 100 & 0.32 & -0.06 & 0.20 & this report \\
$\mathrm{Pt} / \mathrm{TiO}_{2}(\mathrm{R}) \mathrm{L}$ & 150 & 0.60 & -0.54 & 0.01 & this report \\
\hline
\end{tabular}


served only for $\mathrm{Pt} / \mathrm{TiO}_{2}(\mathrm{~A}) \mathrm{L} ; \mathrm{Pt} / \mathrm{TiO}_{2}(\mathrm{R}) \mathrm{L}$ did not show a peak for Pt diffraction. Taken together with the results of the activity measurements, these results indicate that $\mathrm{NH}_{3}$ selectivity in the $\mathrm{NO}-\mathrm{CO}-\mathrm{H}_{2} \mathrm{O}$ reaction in-

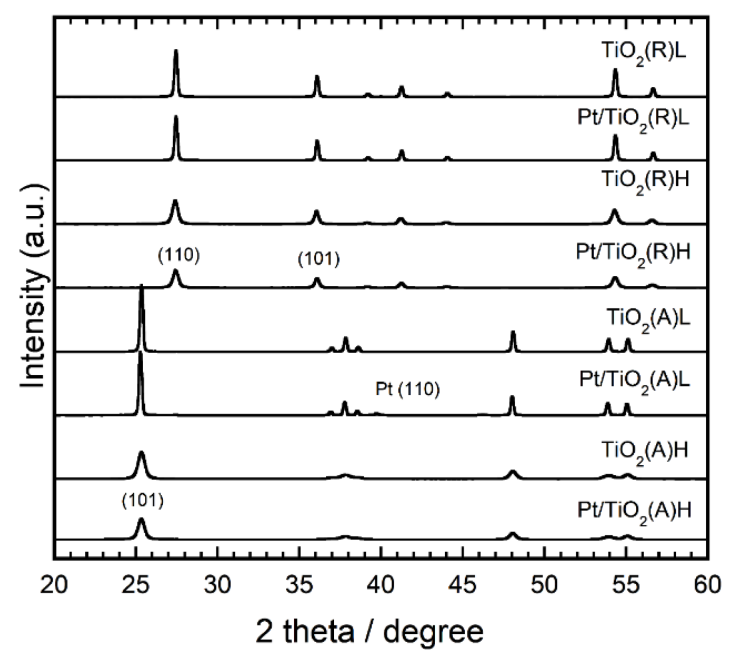

Fig. 3 X-ray Diffraction Patterns of $\mathrm{Pt} / \mathrm{TiO}_{2}$ Catalysts and $\mathrm{TiO}_{2}$ Supports creased with decreasing crystallite size for both anatase and rutile $\mathrm{TiO}_{2}$.

Nitrogen adsorption-desorption isotherms are shown in Fig. 4a. $\mathrm{Pt} / \mathrm{TiO}_{2}(\mathrm{~A}) \mathrm{H}$ and $\mathrm{Pt} / \mathrm{TiO}_{2}(\mathrm{R}) \mathrm{H}$ exhibited a hysteresis loop. The specific surface areas $\left(S_{\mathrm{BET}}\right)$ of the catalysts, as calculated by means of the BrunauerEmmett-Teller equation, are listed in Table 3. The values decreased in the order $\mathrm{Pt} / \mathrm{TiO}_{2}(\mathrm{~A}) \mathrm{H} \gg \mathrm{Pt} /$ $\mathrm{TiO}_{2}(\mathrm{R}) \mathrm{H} \gg \mathrm{Pt} / \mathrm{TiO}_{2}(\mathrm{R}) \mathrm{L}>\mathrm{Pt} / \mathrm{TiO}_{2}(\mathrm{~A}) \mathrm{L} . \quad \mathrm{Pt} / \mathrm{TiO}_{2}(\mathrm{~A})$ $\mathrm{H}$ and $\mathrm{Pt} / \mathrm{TiO}_{2}(\mathrm{R}) \mathrm{H}$ had much larger surface areas than $\mathrm{Pt} / \mathrm{TiO}_{2}(\mathrm{R}) \mathrm{L}$ and $\mathrm{Pt} / \mathrm{TiO}_{2}(\mathrm{~A}) \mathrm{L}$. Pore size distributions were determined by means of the Barrett-Joyner-Halenda method and are shown in Fig. 4b. The mean pore diameters for $\mathrm{Pt} / \mathrm{TiO}_{2}(\mathrm{~A}) \mathrm{H}$ and $\mathrm{Pt} / \mathrm{TiO}_{2}(\mathrm{R}) \mathrm{H}$ were $4.7 \mathrm{~nm}$ and $19 \mathrm{~nm}$, respectively.

Measurements of the activity of the catalysts in the NO-CO- $\mathrm{H}_{2} \mathrm{O}$ reaction revealed that gradual decline was appeared at temperatures at which $\mathrm{NO}$ and $\mathrm{CO}$ conversions exceeded $95 \%$, especially in the case of the $\mathrm{Pt} /$ $\mathrm{TiO}_{2}(\mathrm{~A}) \mathrm{H}$ catalyst. Taken together with the XRD and $\mathrm{N}_{2}$ adsorption results, these results indicate that similar crystallite sizes and the surface area of $\mathrm{Pt} / \mathrm{TiO}_{2}(\mathrm{~A}) \mathrm{H}$ had 1.8 times than that of $\mathrm{Pt} / \mathrm{TiO}_{2}(\mathrm{R}) \mathrm{H}$. Next, we investigated how the chemical aspects of the catalyst
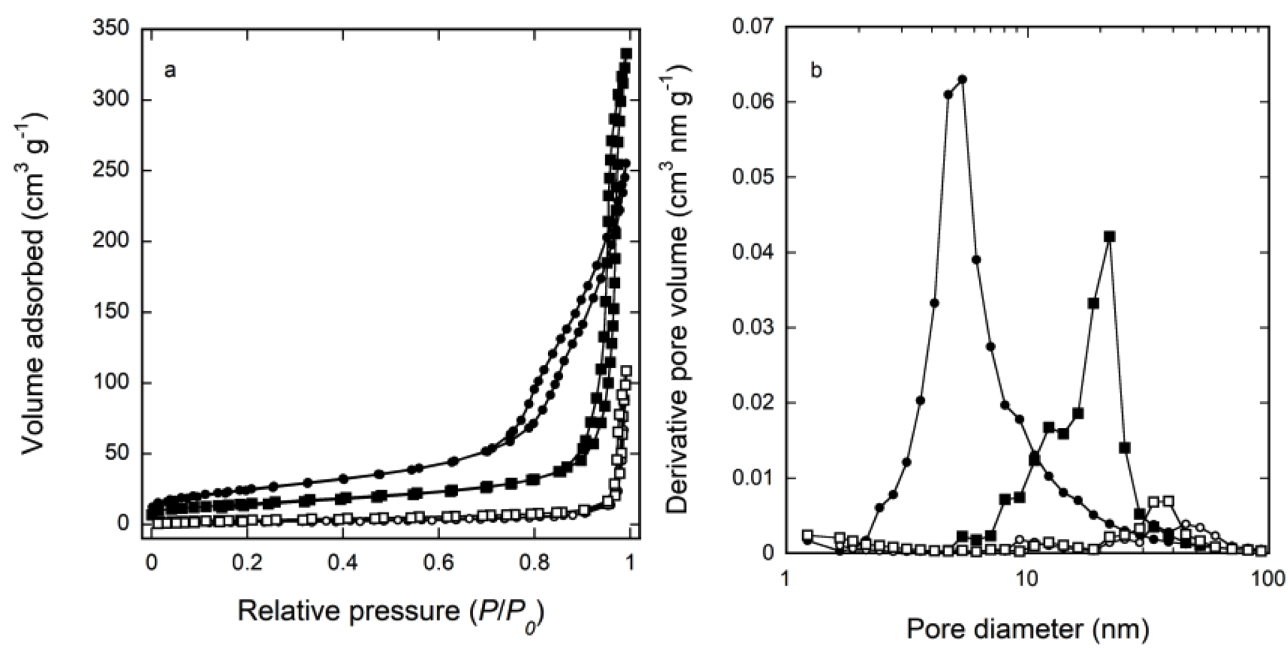

Fig. 4 (a) Nitrogen Adsorption-desorption Isotherms and (b) Pore Size Distributions for $\mathrm{Pt} / \mathrm{TiO}_{2}(\mathrm{~A}) \mathrm{H}$ $\mathrm{Pt} / \mathrm{TiO}_{2}(\mathrm{~A}) \mathrm{L}(\mathrm{O}), \mathrm{Pt} / \mathrm{TiO}_{2}(\mathrm{R}) \mathrm{H}(\square)$, and $\mathrm{Pt} / \mathrm{TiO}_{2}(\mathrm{R}) \mathrm{L}(\square)$

Table 3 Physical Properties of Pt Catalysts

\begin{tabular}{|c|c|c|c|c|c|c|}
\hline \multirow{2}{*}{ Catalyst } & \multirow{2}{*}{ Crystallite size $^{\mathrm{a})}[\mathrm{nm}]$} & \multirow{2}{*}{$S_{\text {BET }}\left[\mathrm{m}^{2} \mathrm{~g}^{-1}\right]$} & \multirow{2}{*}{$d_{\mathrm{BJH}}{ }^{\mathrm{b})}[\mathrm{nm}]$} & \multirow{2}{*}{$\mathrm{CO} / \mathrm{Pt}$} & \multicolumn{2}{|c|}{ Mean Pt particle size [nm } \\
\hline & & & & & $\mathrm{CO}$ pulse & TEM \\
\hline $\mathrm{Pt} / \mathrm{TiO}_{2}(\mathrm{~A}) \mathrm{H}$ & $19(18)$ & 93 & 4.7 & 0.32 & 3.5 & 1.3 \\
\hline $\mathrm{Pt} / \mathrm{TiO}_{2}(\mathrm{~A}) \mathrm{L}$ & $43(42)$ & 7.9 & - & 0.04 & 28 & 1.6 \\
\hline $\mathrm{Pt} / \mathrm{TiO}_{2}(\mathrm{R}) \mathrm{H}$ & $22(22)$ & 53 & 19 & 0.26 & 4.4 & 1.1 \\
\hline $\mathrm{Pt} / \mathrm{TiO}_{2}(\mathrm{R}) \mathrm{L}$ & $42(41)$ & 12 & - & 0.34 & 3.4 & 1.7 \\
\hline
\end{tabular}

a) Calculated by means of the Scherrer equation using the half-widths of the anatase $\mathrm{TiO}_{2}(101)$ and rutile $\mathrm{TiO} \mathrm{O}_{2}(110)$ peaks, respectively. Numbers in parentheses are the crystallite sizes of the supports.

b) Mean pore diameter. 

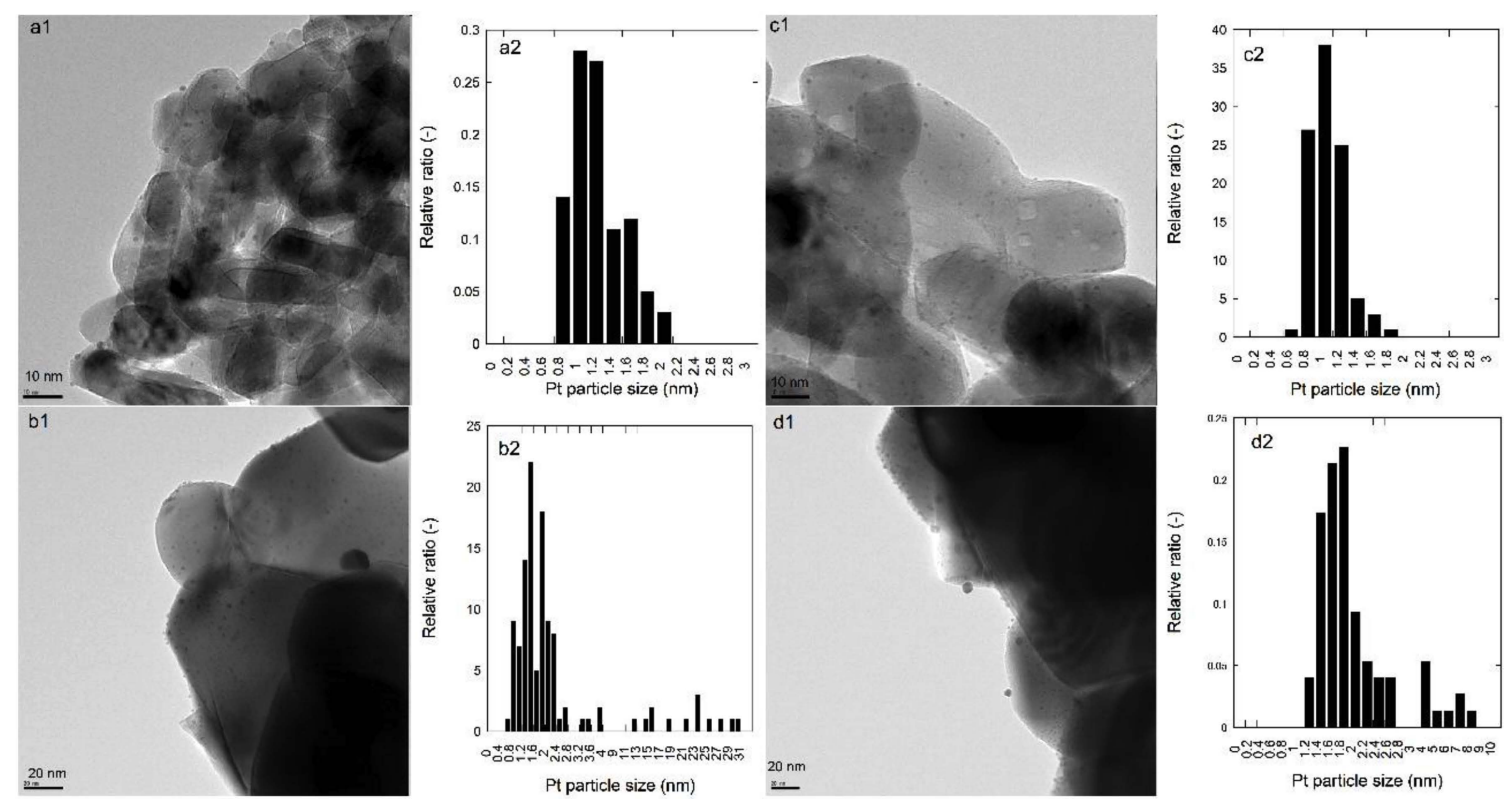

Fig. 5 Transmission Electron Microscopy Images (a1-d1) and Pt Particle Size Distributions of $\mathrm{Pt}^{\mathrm{T}} \mathrm{TiO}_{2}$ Catalysts (a2-d2): (a) (A)H, (b) (A)L, (c) (R)H, and (d) (R)L

surface related with the activity.

\section{5. 2. CO Pulse Adsorption and Transmission Electron Microscopy Measurement}

To determine the morphology of the Pt particles, we carried out $\mathrm{CO}$ pulse adsorption experiments; the $\mathrm{CO} / \mathrm{Pt}$ molar adsorption ratios and estimated mean particle sizes are listed in Table 3. Comparison of the CO/Pt ratios for the four catalysts suggests that Pt dispersion on anatase $\mathrm{TiO}_{2}$ depended on specific surface area, whereas that on rutile $\mathrm{TiO}_{2}$ did not. The mean particle sizes estimated on the basis of $\mathrm{CO}$ adsorption were 3.5, 28, 4.4, and $3.4 \mathrm{~nm}$ for $\mathrm{Pt} / \mathrm{TiO}_{2}(\mathrm{~A}) \mathrm{H}, \mathrm{Pt} / \mathrm{TiO}_{2}(\mathrm{~A}) \mathrm{L}, \mathrm{Pt} /$ $\mathrm{TiO}_{2}(\mathrm{R}) \mathrm{H}$, and $\mathrm{Pt} / \mathrm{TiO}_{2}(\mathrm{R}) \mathrm{L}$, respectively. To obtain additional information about Pt particle size, we also obtained TEM images (Fig. 5) and used them to calculate particle size distributions (Table 3). Comparison of the mean particle sizes calculated on the basis of $\mathrm{CO}$ adsorption and TEM revealed that the two values for Pt/ $\mathrm{TiO}_{2}(\mathrm{~A}) \mathrm{H}$ and $\mathrm{Pt} / \mathrm{TiO}_{2}(\mathrm{R}) \mathrm{H}$ were comparable, suggesting that the dispersion of Pt particles observed in Fig. 5a were representative of the entire surface. For $\mathrm{Pt} / \mathrm{TiO}_{2}(\mathrm{~A}) \mathrm{L}$ and $\mathrm{Pt} / \mathrm{TiO}_{2}(\mathrm{R}) \mathrm{L}$, the values determined by $\mathrm{CO}$ adsorption were higher than the TEM values. The particle size distributions for these two catalysts indicate that there were some relatively large Pt particles, which would have increased the mean particle size as measured by $\mathrm{CO}$ adsorption. For $\mathrm{Pt} / \mathrm{TiO}_{2}(\mathrm{~A}) \mathrm{L}$, the mean particle size based on $\mathrm{CO}$ adsorption was much larger than that based on TEM. As shown in Fig. 5b, there were in fact some large Pt particles in this catalyst. Although the TEM image of $\mathrm{Pt} / \mathrm{TiO}_{2}(\mathrm{~A}) \mathrm{L}$ showed small Pt particles, Pt particles would be mainly consisted of the large agglomeration. Consideration of the size and morphology of the Pt particles on $\mathrm{TiO}_{2}(\mathrm{~A}) \mathrm{H}$ and $\mathrm{TiO}_{2}(\mathrm{R}) \mathrm{H}$ indicated that there was no correlation between activity and Pt morphology. This result suggests that the physical properties of Pt were the critical determinant of activity. Therefore, we focused on the differences in chemical properties.

2. 6. Characterization of Chemical Properties

2. 6. 1. Temperature Programmed Reduction by Hydrogen Measurement

The $\mathrm{H}_{2}$-TPR profile of $\mathrm{Pt} / \mathrm{TiO}_{2}(\mathrm{~A}) \mathrm{H}$ (Fig. 6a) showed reduction peaks at $126{ }^{\circ} \mathrm{C}$ and $200-560{ }^{\circ} \mathrm{C}$, which were attributed to reduction of $\mathrm{PtO}_{x}$ species and surface oxygen of $\mathrm{TiO}_{2}$, respectively ${ }^{22)}$. In the profile for $\mathrm{TiO}_{2}(\mathrm{~A}) \mathrm{H}$, the peaks at $370-715{ }^{\circ} \mathrm{C}$ were attributed to surface oxygen of $\mathrm{TiO}_{2}$. The fact that the $\mathrm{TiO}_{2}$ reduction peak for $\mathrm{Pt} / \mathrm{TiO}_{2}(\mathrm{~A}) \mathrm{H}$ appeared at a much lower temperature than that for $\mathrm{TiO}_{2}(\mathrm{~A}) \mathrm{H}$ suggests a strong interaction between $\mathrm{Pt}$ and $\mathrm{TiO}_{2}{ }^{23)}$. For $\mathrm{Pt} / \mathrm{TiO}_{2}(\mathrm{R}) \mathrm{H}$ (Fig. 6b), reduction peaks were observed at 126, 379, and $635{ }^{\circ} \mathrm{C}$ and were attributed to $\mathrm{PtO}_{x}$ species, surface oxygen of $\mathrm{TiO}_{2}$, and some of the bulk $\mathrm{TiO}_{2}$, respective$1 \mathrm{y}^{22), 24)}$. The reduction peaks for $\mathrm{TiO}_{2}(\mathrm{R}) \mathrm{H}$ appeared at $16{ }^{\circ} \mathrm{C}$ and $430-730{ }^{\circ} \mathrm{C}$. These results suggest that the interaction between $\mathrm{Pt}$ and rutile $\mathrm{TiO}_{2}$ was also strong. In our previous study, we observed a small reduction peak at $50{ }^{\circ} \mathrm{C}$ for rutile $\mathrm{TiO}_{2}\left(5 \mathrm{~m}^{2} \mathrm{~g}^{-1}\right)$, and there was no peak shift due to Pt loading ${ }^{11)}$. Comparison of these previous results suggests that when the $\mathrm{TiO}_{2}$ support has a high specific surface area (small crystallite size), $\mathrm{Pt}$ and $\mathrm{TiO}_{2}$ interact strongly, regardless of the crystal structure. The temperature for the $\mathrm{PtO}_{x}$ reduction peak was the same for both $\mathrm{Pt} / \mathrm{TiO}_{2}(\mathrm{~A}) \mathrm{H}$ and $\mathrm{Pt} / \mathrm{TiO}_{2}(\mathrm{R}) \mathrm{H}$, suggesting that $\mathrm{Pt}$ particles on these 
supports had similar reducibilities. These results indicate that the chemical properties of $\mathrm{Pt}$, such as reducibility and $\mathrm{Pt}^{-} \mathrm{TiO}_{2}$ interactions, were similar, despite that fact that the reducibilities of anatase and rutile $\mathrm{TiO}_{2}$ differed, and their surface chemical properties can be expected to differ.

\section{6. 2. Temperature Programmed Desorption by Carbon Dioxide}

To evaluate the differences in their surface chemical properties, we investigated the desorption behavior of the $\mathrm{CO}_{2}$ product gas by means of $\mathrm{CO}_{2}-\mathrm{TPD}$; profiles for $\mathrm{Pt} / \mathrm{TiO}_{2}(\mathrm{~A}) \mathrm{H}$ and $\mathrm{Pt} / \mathrm{TiO}_{2}(\mathrm{R}) \mathrm{H}$ are shown in Fig. 7. The profile for $\mathrm{Pt} / \mathrm{TiO}_{2}(\mathrm{~A}) \mathrm{H}$ had one desorption peak (at $66{ }^{\circ} \mathrm{C}$ ), whereas the profile for $\mathrm{Pt} / \mathrm{TiO}_{2}(\mathrm{R}) \mathrm{H}$ had three peaks (at 67,135 [shoulder], and $288^{\circ} \mathrm{C}$ ). The amount of $\mathrm{CO}_{2}$ desorbed from $\mathrm{Pt} / \mathrm{TiO}_{2}(\mathrm{R})$ was larger than the amount desorbed from $\mathrm{Pt} / \mathrm{TiO}_{2}(\mathrm{~A}) \mathrm{H}$, indicating that $\mathrm{Pt} /$ $\mathrm{TiO}_{2}(\mathrm{R}) \mathrm{H}$ adsorbed $\mathrm{CO}_{2}$ more strongly than $\mathrm{Pt} / \mathrm{TiO}_{2}(\mathrm{~A})$ $\mathrm{H}$ did. Because decline $\mathrm{CO}$ conversion was observed on $\mathrm{Pt} / \mathrm{TiO}_{2}(\mathrm{~A}) \mathrm{H}$, we suspect that the interaction between $\mathrm{CO}_{2}$ and the rutile $\mathrm{TiO}_{2}$ surface was less related to the activity. To clarify the effect of the $\mathrm{CO}_{2}$ generated during the NO-CO- $\mathrm{H}_{2} \mathrm{O}$ reaction, we carried out NO$\mathrm{CO}-\mathrm{H}_{2} \mathrm{O}-\mathrm{CO}_{2}$ reactions over $\mathrm{Pt} / \mathrm{TiO}_{2}(\mathrm{~A}) \mathrm{H}$ and $\mathrm{Pt} /$ $\mathrm{TiO}_{2}(\mathrm{R}) \mathrm{H}$ (Fig. 8). For both catalysts, the temperature dependence of $\mathrm{NO}$ conversion during the $\mathrm{NO}^{-} \mathrm{CO}^{-}$ $\mathrm{H}_{2} \mathrm{O}-\mathrm{CO}_{2}$ reaction was almost identical to that during the $\mathrm{NO}-\mathrm{CO}-\mathrm{H}_{2} \mathrm{O}$ reaction (Fig. 8a), and the same was true for the temperature dependence of $\mathrm{NO}$ conversion to $\mathrm{NH}_{3}$ (Fig. 8b). These results suggest that the $\mathrm{CO}_{2}$ produced during the NO-CO- $\mathrm{H}_{2} \mathrm{O}$ reaction did not influenced to activity.

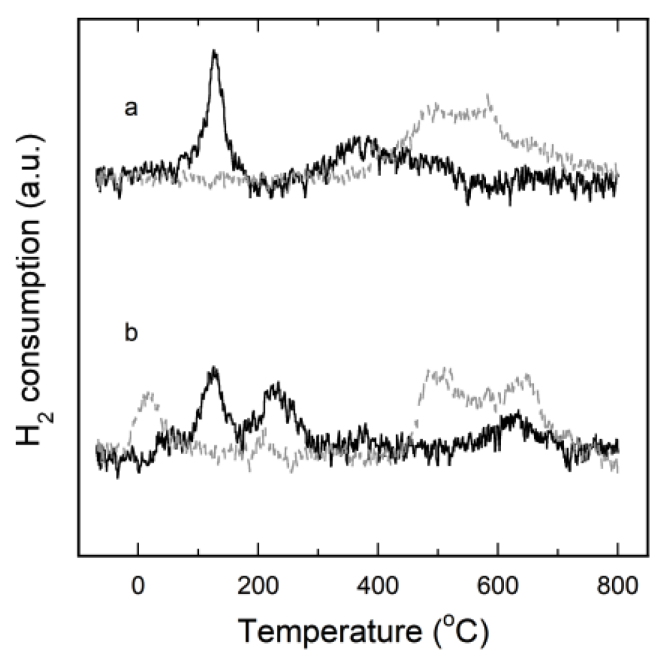

Fig. $6 \mathrm{H}_{2}$-Temperature-programmed Reduction Profiles of Pt/ $\mathrm{TiO}_{2}(\mathrm{~A}) \mathrm{H}$ (a, black), $\mathrm{TiO}_{2}(\mathrm{~A}) \mathrm{H}$ (a, gray), $\mathrm{Pt} / \mathrm{TiO}_{2}(\mathrm{R}) \mathrm{H}$ (b, black), and $\mathrm{TiO}_{2}(\mathrm{R}) \mathrm{H}$ (b, gray)

\section{6.3. Diffuse Reflectance Infrared Fourier Transform Spectroscopy and Temperature Programmed Desorption by Ammonia}

DRIFTS measurement was carried out to confirm intermediates during the $\mathrm{NO}-\mathrm{CO}-\mathrm{H}_{2} \mathrm{O}$ reaction on $\mathrm{Pt} /$ $\mathrm{TiO}_{2}(\mathrm{~A}) \mathrm{H}$ and $\mathrm{Pt} / \mathrm{TiO}_{2}(\mathrm{R}) \mathrm{H}$ at $150{ }^{\circ} \mathrm{C}$ and $200{ }^{\circ} \mathrm{C}$, and the results are shown in Fig. 9. In the spectra of $\mathrm{Pt} /$ $\mathrm{TiO}_{2}(\mathrm{~A}) \mathrm{H}$ during the NO-CO- $\mathrm{H}_{2} \mathrm{O}$ reaction at $150{ }^{\circ} \mathrm{C}$ and $200{ }^{\circ} \mathrm{C}$ was confirmed negative peak at 3650 $3500 \mathrm{~cm}^{-1}$ and positive peak at $3500-3100 \mathrm{~cm}^{-1}$ in Fig. 9a (i, iii), and these peaks were attributed to surface $\mathrm{OH}$ groups on $\mathrm{TiO}_{2}$ and $\mathrm{NH}_{x}$ species. Negative peak means that $\mathrm{OH}$ groups were consumed in the reaction. Similarly, negative peak at $3800-3550 \mathrm{~cm}^{-1}$ and $3500-3100 \mathrm{~cm}^{-1}$ was confirmed on $\mathrm{Pt} / \mathrm{TiO}_{2}(\mathrm{R}) \mathrm{H}$. The spectra at 1590,1530,1428,1379, 1367, 1220 and $1180 \mathrm{~cm}^{-1}$ were observed on $\mathrm{Pt} / \mathrm{TiO}_{2}(\mathrm{~A}) \mathrm{H}$ in Fig. 9b-i. The peaks at $1590 \mathrm{~cm}^{-1}$ and $1220 \mathrm{~cm}^{-1}$ were attributed to nitrate species ${ }^{25)}$. The peaks at $1428 \mathrm{~cm}^{-1}$ and $1180 \mathrm{~cm}^{-1}$ were attributed to vending symmetry of $\mathrm{NH}_{3}{ }^{26), 27)}$. The peaks at 1530,1379 and $1367 \mathrm{~cm}^{-1}$ were attributed to formate species ${ }^{28), 29)}$. For Pt/ $\mathrm{TiO}_{2}(\mathrm{R}) \mathrm{H}$, the peaks at $1600,1545,1435,1381,1362$, 1350, 1224 and $1181 \mathrm{~cm}^{-1}$ were observed (Fig. 9b-ii). The peaks at $1600 \mathrm{~cm}^{-1}$ and $1224 \mathrm{~cm}^{-1}$ were attributed to nitrate species ${ }^{25)}$. The peaks at $1428 \mathrm{~cm}^{-1}$ and $1181 \mathrm{~cm}^{-1}$ were attributed to vending symmetry of $\mathrm{NH}_{3}{ }^{26), 27)}$. The peaks at $1545,1381,1362$ and $1350 \mathrm{~cm}^{-1}$ was attributed to formate species ${ }^{28), 29)}$. All peaks became smaller with increasing temperature. It is noted that the peaks attributed to formate species on $\mathrm{Pt} / \mathrm{TiO}_{2}(\mathrm{~A}) \mathrm{H}$ were almost disappeared at $200{ }^{\circ} \mathrm{C}$. Taking into account of lower $\mathrm{CO}$ conversion at around $200{ }^{\circ} \mathrm{C}$ in the $\mathrm{NO}-\mathrm{CO}-\mathrm{H}_{2} \mathrm{O}$ reaction than that in the $\mathrm{CO}^{-}$ $\mathrm{H}_{2} \mathrm{O}$ reaction, decrease in peak intensity for formate

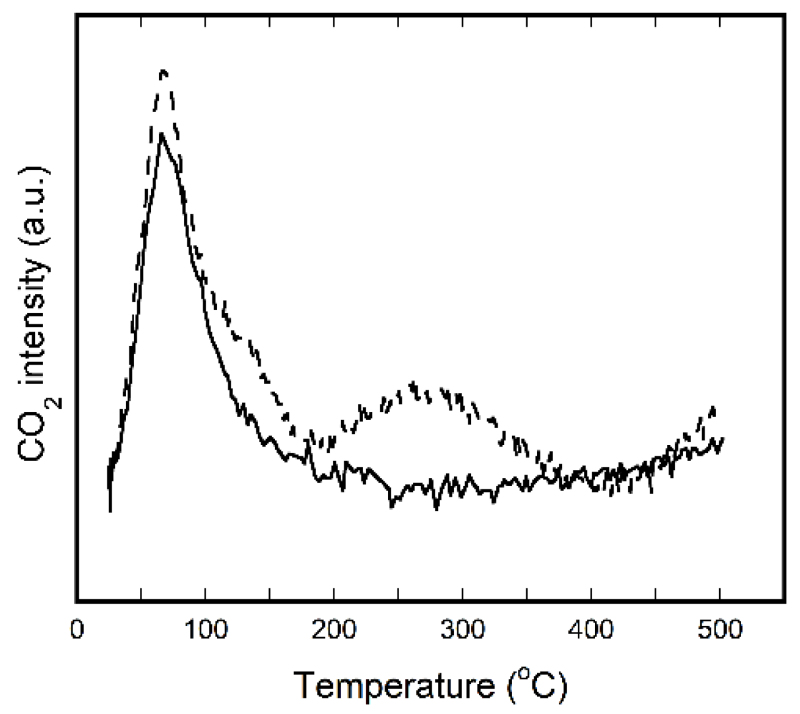

Fig. $7 \mathrm{CO}_{2}$-Temperature-programmed Desorption Profiles of $\mathrm{Pt} /$ $\mathrm{TiO}_{2}(\mathrm{~A}) \mathrm{H}$ (solid line) and $\mathrm{Pt} / \mathrm{TiO}_{2}(\mathrm{R}) \mathrm{H}$ (dashed line) 

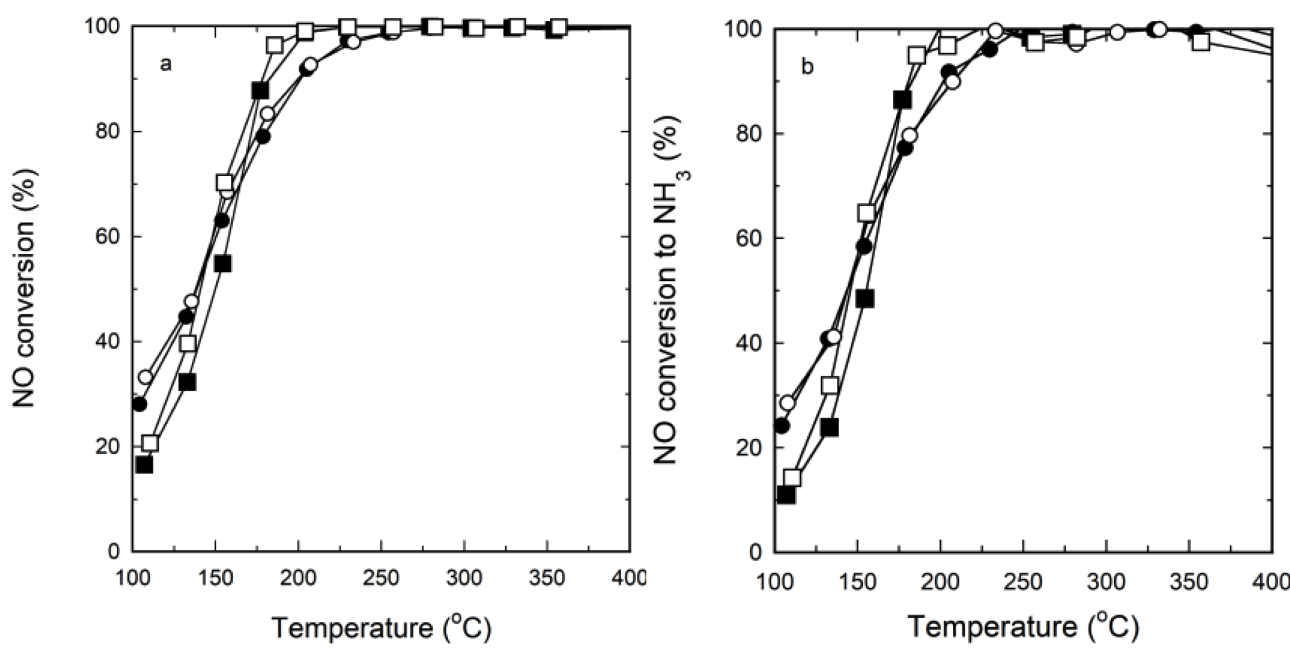

Fig. 8 Temperature Dependence of (a) NO Conversion and (b) NO Conversion to $\mathrm{NH}_{3}$ for $\mathrm{Pt} / \mathrm{TiO}_{2}(\mathrm{~A}) \mathrm{H}(\mathbf{O})$ and $\mathrm{Pt} / \mathrm{TiO}_{2}(\mathrm{R}) \mathrm{H}(\square)$ for a Reaction Mixture Consisting of $0.1 \% \mathrm{NO}, 0.3 \% \mathrm{CO}, 1 \% \mathrm{H}_{2} \mathrm{O}$, and $1 \% \mathrm{CO}_{2}$ with Argon as the Balance Gas; and $\mathrm{Pt} / \mathrm{TiO}_{2}(\mathrm{~A}) \mathrm{H}(\mathrm{O})$ and $\mathrm{Pt} / \mathrm{TiO}_{2}(\mathrm{R}) \mathrm{H}(\square)$ for a Reaction Mixture Consisting of $0.1 \% \mathrm{NO}, 0.3 \% \mathrm{CO}$, and $1 \% \mathrm{H}_{2} \mathrm{O}$ with Argon as the Balance Gas
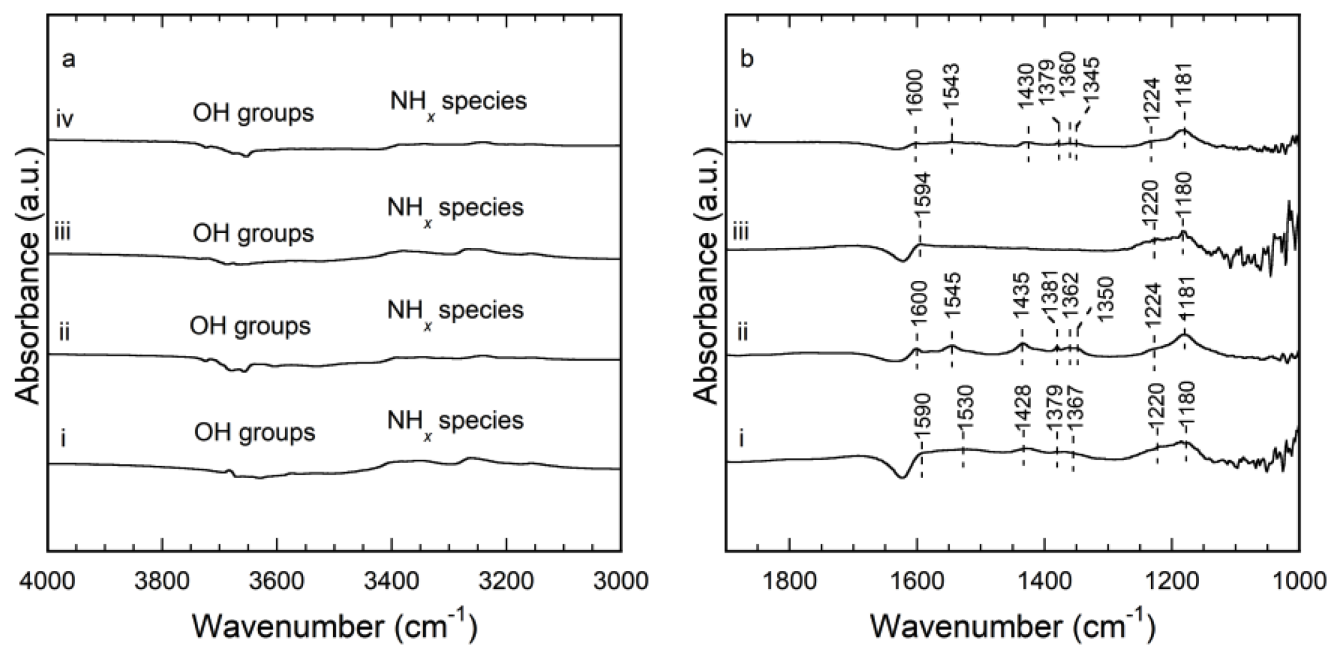

Reaction mixture: $0.1 \% \mathrm{NO}, 0.3 \% \mathrm{CO}$ and $0.5 \% \mathrm{H}_{2} \mathrm{O}$ in helium. Reaction temperature was $150{ }^{\circ} \mathrm{C}$ (i, ii) and $200{ }^{\circ} \mathrm{C}$ (iii, iv).

Fig. 9 Diffuse Reflectance Infrared Fourier Transform Spectra of $\mathrm{Pt} / \mathrm{TiO}_{2}(\mathrm{~A}) \mathrm{H}$ (i, iii) and $\mathrm{Pt} / \mathrm{TiO}_{2}(\mathrm{R}) \mathrm{H}$ (ii, iv)

species is suspected to relate with the decline of $\mathrm{CO}$ conversion. $\mathrm{NH}_{3}$ formation at around $200{ }^{\circ} \mathrm{C}$ in the $\mathrm{NO}-\mathrm{CO}-\mathrm{H}_{2} \mathrm{O}$ reaction responded to suppressed $\mathrm{CO}$ conversion. Since the $\mathrm{CO}-\mathrm{H}_{2} \mathrm{O}$ reaction could supply hydrogen to form $\mathrm{NH}_{3}$, the formate species was likely to be a supply source of hydrogen to form $\mathrm{NH}_{3}$ in the $\mathrm{NO}-\mathrm{CO}-\mathrm{H}_{2} \mathrm{O}$ reaction.

We carried out $\mathrm{NH}_{3}$-TPD to investigate the effect of formed $\mathrm{NH}_{3}$ adsorption on the activity of the $\mathrm{NO}^{-} \mathrm{CO}^{-}$ $\mathrm{H}_{2} \mathrm{O}$ reaction. The $\mathrm{NH}_{3}$ evolution profiles for $\mathrm{Pt} /$ $\mathrm{TiO}_{2}(\mathrm{~A}) \mathrm{H}$ and $\mathrm{Pt} / \mathrm{TiO}_{2}(\mathrm{R}) \mathrm{H}$ are shown in Fig. 10. For $\mathrm{Pt} / \mathrm{TiO}_{2}(\mathrm{~A}) \mathrm{H}, \mathrm{NH}_{3}$ evolution peaks appeared at $104{ }^{\circ} \mathrm{C}$ and $262{ }^{\circ} \mathrm{C}$; for $\mathrm{Pt} / \mathrm{TiO}_{2}(\mathrm{R}) \mathrm{H}$, there were peaks at $108{ }^{\circ} \mathrm{C}$ and $287{ }^{\circ} \mathrm{C}$. These results suggest that strength of acid sites was similar. The area of $\mathrm{NH}_{3}$ desorption profile for $\mathrm{Pt} / \mathrm{TiO}_{2}(\mathrm{~A}) \mathrm{H}$ was larger than that for $\mathrm{Pt} /$ $\mathrm{TiO}_{2}(\mathrm{R}) \mathrm{H}$, though the desorption amounts of $\mathrm{NH}_{3}$ per unit surface area for $\mathrm{Pt} / \mathrm{TiO}_{2}(\mathrm{~A}) \mathrm{H}$ and $\mathrm{Pt} / \mathrm{TiO}_{2}(\mathrm{R}) \mathrm{H}$ were 1.4 intensity $/ \mathrm{m}^{2}$ and 1.3 intensity $/ \mathrm{m}^{2}$, respectively. These results suggest that the acidic properties of the high-surface-area $\mathrm{TiO}_{2}$ supported Pt catalysts were similar. So, effect of the acidic property of $\mathrm{TiO}_{2}$ surface on the catalytic activity was excluded.

\section{Conclusions}

We investigated the $\mathrm{NO}^{-} \mathrm{CO}-\mathrm{H}_{2} \mathrm{O}$ reaction and $\mathrm{CO}^{-}$ $\mathrm{H}_{2} \mathrm{O}$ reaction over $\mathrm{Pt}$ supported on rutile and anatase 


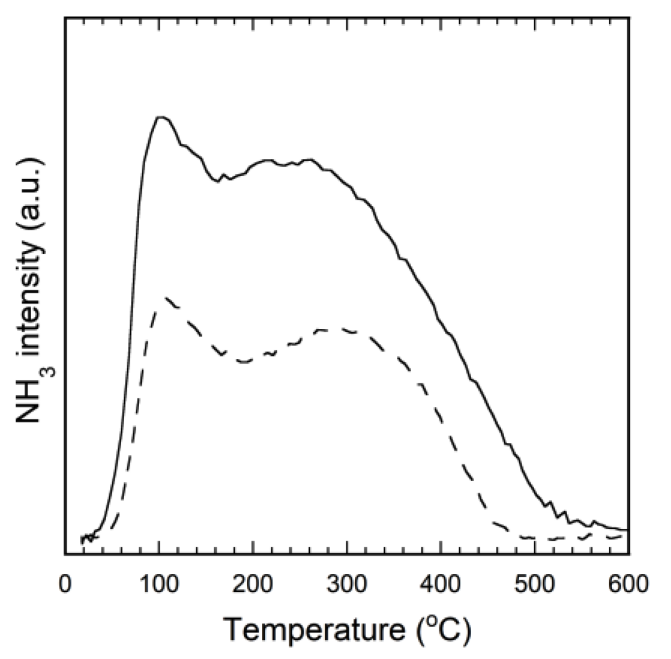

Fig. $10 \mathrm{NH}_{3}$-Temperature-programmed Desorption Profiles of Pt/ $\mathrm{TiO}_{2}(\mathrm{~A}) \mathrm{H}$ (solid line) and $\mathrm{Pt} / \mathrm{TiO}_{2}(\mathrm{R}) \mathrm{H}$ (dashed line)

$\mathrm{TiO}_{2}$ with high and low specific surface areas. Catalytic activity tests of $\mathrm{NO}-\mathrm{CO}-\mathrm{H}_{2} \mathrm{O}$ reaction revealed that at around $100{ }^{\circ} \mathrm{C}, \mathrm{Pt} / \mathrm{TiO}_{2}(\mathrm{~A}) \mathrm{H}$, which has a high specific surface area, showed higher activity than the other three tested catalysts; although $\mathrm{Pt} / \mathrm{TiO}_{2}(\mathrm{R}) \mathrm{H}$, which also has high specific surface area, showed $100 \%$ NO conversion to $\mathrm{NH}_{3}$ at a lower temperature than $\mathrm{Pt} / \mathrm{TiO}_{2}(\mathrm{~A})$ $\mathrm{H}$. The catalytic activity test of $\mathrm{CO}-\mathrm{H}_{2} \mathrm{O}$ reaction showed difference in activity of $\mathrm{CO}$ conversion on $\mathrm{Pt} /$ $\mathrm{TiO}_{2}(\mathrm{~A}) \mathrm{H}$ compared to $\mathrm{Pt} / \mathrm{TiO}_{2}(\mathrm{R}) \mathrm{H}$. The two $\mathrm{Pt} / \mathrm{TiO}_{2}$ catalysts with low specific surface areas exhibited lower activity for $\mathrm{NO}-\mathrm{CO}-\mathrm{H}_{2} \mathrm{O}$ reaction than the two catalysts with high specific surface areas. Measurements of the kinetic parameters revealed that the reaction orders with respect to $\mathrm{CO}$ and $\mathrm{H}_{2} \mathrm{O}$ depended not on the crystal structure of the $\mathrm{TiO}_{2}$ but on its surface area. The $\mathrm{TiO}_{2}$ crystal structure was found to influence the activity. XRD analysis, pore size distributions calculated by means of $\mathrm{N}_{2}$ adsorption experiments, and Pt dispersions calculated by means of $\mathrm{CO}$ pulse adsorption experiments and TEM showed no clear relationship between these results and catalytic activity. $\mathrm{CO}_{2}$-TPD and tests of the catalyst activities in the $\mathrm{NO}-\mathrm{CO}-\mathrm{H}_{2} \mathrm{O}-\mathrm{CO}_{2}$ reaction revealed that the $\mathrm{CO}_{2}$ produced by the $\mathrm{NO}_{-} \mathrm{CO}^{-}$ $\mathrm{H}_{2} \mathrm{O}$ reaction did not affected to activity. DRIFTS measurements of these catalysts suggested that the behavior of formate species against temperature was different at $200{ }^{\circ} \mathrm{C}$ between anatase and rutile $\mathrm{TiO}_{2}$ support. Adsorbed $\mathrm{NH}_{3}$ observed by DRIFTS was no related to difference in activity. We suspect that behavior of formate species formation on the catalyst surfaces was related to $\mathrm{NH}_{3}$ formation. Therefore, we concluded that difference of crystalline structure of $\mathrm{TiO}_{2}$ influenced on the surface formate species formation, and then catalytic activity of $\mathrm{NH}_{3}$ formation in the NO-CO- $\mathrm{H}_{2} \mathrm{O}$ reaction was affected on the surface spe- cies.

\section{Acknowledgment}

The authors thank Mr. Takatsuki of the National Institute of Advanced Industrial Science and Technology (AIST), Tsukuba, for the TEM observations.

\section{References}

1) Rockström, J., Steffen, W., Noone, K., Persson, ̊., Chapin III, S. F., Lambin, F. E., Lenton, M. T., Scheffer, M., Folke, C., Schellnhuber, J. H., Nykvist, B., de Wit, A. C., Hughes, T., van der Leeuw, S., Rodhe, H., Sörlin, S., Snyder, K. P., Costanza, R., Svedin, U., Falkenmark, M., Karlberg, L., Corell, W. R., Fabry, J. V., Hansen, J., Walker, B., Liverman, D., Richardson, K., Crutzen, P., Foley, A . J., Nature, 461, 472 (2009).

2) Fowler, D., Coyle, M., Skiba, U., Sutton, A. M., Cape, N. J., Reis, S., Sheppard, J. L., Jenkins, A., Grizzetti, B., Galloway, N. J., Vitousek, P., Leach, A., Bouwman, F. A., Butterbach-Bahl, K., Dentener, F., Stevenson, D., Amann, M., Voss, M., Philos. Trans. Royal Soc. B, 368, 1621 (2013).

3) Yang, Y., Liu, J., Wang, Z., Liu, F., Fuel Proces. Tech., 174, 17 (2018).

4) Pereda-Ayo, B., Duraiswami, D., Gonzalez-Velasco, R. J., Catal. Today, 172, 66 (2011).

5) Gao, X., Jiang, Y., Zhong, Y., Luo, Z., Cen, K., J. Hazard. Mat., 174, 734 (2010).

6) Tang, C., Zhang, H., Dong, L., Catal. Sci. Tech., 6, 1248 (2016).

7) Shan, W., Song, H., Catal. Sci. Tech., 5, 4280 (2015).

8) Jung, Y., Pyo, D. Y., Jang, J., Kim, C. G., Cho, P. C., Yang, C., Chem. Eng., 369, 1059 (2019).

9) Kojima, Y., Inter. J. Hyd. Energy, 44, 18179 (2019).

10) Giddey, S., Badwal, S. P. S., Munnings, C., Dolan, M., ACS Sustain. Chem. Eng., 5, 10231 (2017).

11) Kobayashi, K., Atsumi, R., Manaka, Y., Matsumoto, H., Nanba, T., Catal. Sci. Tech., 9, 2898 (2019).

12) Chambers, C. D., Angove, E. D., Cant, W. N., J. Catal., 204, 11 (2001).

13) Cant, W. N., Chambers, C. D., Liu, Y. O. I., Appl. Catal. B: Environment., 46, 551 (2003).

14) Dasari, R. P., Muncrief, R., Harold, P. M., Catal. Today, 184, 43 (2012).

15) Adams, C. E., Skoglundh, M., Elmøe, T., Carlsson, P.-A., Catal. Today, 307, 169 (2018).

16) Nanba, T., Meuier, C. F., Hardancre, C., Burch, P. J., Masukawa, S., Uchisawa, J., Obuchi, A., J. Phys. C, 112, 18157 (2008).

17) Mergler, J. Y., Nieuwenhuys, E. B., Appl. Catal. B: Environment., 12, 95 (1997).

18) Nanba, T., Masukawa, S., Uchisawa, J., Obuchi, A., Chem. Lett., 37, 710 (2008).

19) Pal, M., Serrano, G. J., Santiago, P., Pal, U., J. Phys. Chem. C, 111, 96 (2007).

20) Park, C. G., Seo, Y. T., Park, H. C., Lim, H. J., Joo, J., Ind. Eng. Chem. Res., 56, 8235 (2017).

21) Tian, G., Fu, H., Jing, L., Tian, C., J. Hazard. Mat., 161, 1122 (2009).

22) Pérez-Hernández, R., Gómez-Cortés, A., Arenas-Alatorre, J., Rojas, S., Mariscal, R., Fierro, G. L. J., Díaz, G., Catal. Today, 107-108, 149 (2005)

23) Baker, K. T. R., Prestridge, B. E., Garten, L. R., J. Catal., 59, 293 (1979).

24) Kim, S., Lee, H., Hong, C. S., Appl. Catal. B: Environment., 119-120, 100 (2012).

25) Tang, N., Liu, Y., Wang, H., Wu, Z., J. Phys. Chem. C, 115, 8214 (2011). 
26) Hadjiivanov, K., Appl. Sur. Sci., 135, 331 (1998).

27) Labalme, V., Béguin, B., Gaillard, F., Primet, M., Appl. Catal. A: General, 192, 307 (2000).

28) Zhang, C., He, H., Tanaka, K., Appl. Catal. B: Environment.,
65, 37 (2006).

29) Panagiotopoulou, P., Christodoulakis, A., Kondarides, I. D., Boghosian, S., J. Catal., 240, 114 (2006).

要旨

\title{
酸化チタン担持白金触媒上での水存在下の一酸化窒素の一酸化炭素による還元における 担体表面特性に対する活性への影響
}

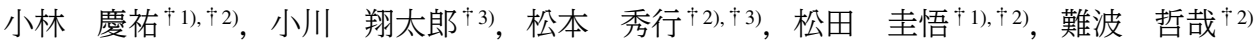 \\ †1) 山形大学大学院理工学研究科物質化学工学専攻, 992-8510 山形県米沢市城南4-3-16 \\ †2) (国研) 産業技術総合研究所 再生可能エネルギー研究センター, 963-0298 福島県郡山市待池台2-2-9 \\ †3) 東京工業大学物質理工学院，152-8550 東京都目黒区大岡山2-12-1
}

燃焼プロセスから放出される反応性窒素種を有用な化合物の 合成の原料として利用する方法を開発することを目標に，Pt/ $\mathrm{TiO}_{2}$ 触媒上での $\mathrm{NO}-\mathrm{CO}-\mathrm{H}_{2} \mathrm{O}$ 反応を利用して, $\mathrm{NO}$ から $\mathrm{NH}_{3}$ へ の選択的変換を検討した。触媒活性試験により, $250{ }^{\circ} \mathrm{C}$ 未満で は高比表面積担体を用いた触媒の活性が担体の結晶構造に依存 することが明らかになった。 $\mathrm{NH}_{3}$ 生成に必要な水素の供給反応 の一つと考えられる $\mathrm{CO}-\mathrm{H}_{2} \mathrm{O}$ と $\mathrm{NO}-\mathrm{CO}-\mathrm{H}_{2} \mathrm{O}$ 反応の $\mathrm{CO}$ 転化率 を比較した。ルチル型 $\mathrm{TiO}_{2}$ 担持白金触媒は $\mathrm{NO}-\mathrm{CO}-\mathrm{H}_{2} \mathrm{O}$ 反応 の $\mathrm{CO}$ 転化率が $\mathrm{CO}-\mathrm{H}_{2} \mathrm{O}$ 反応の $\mathrm{CO}$ 転化率よりも高くなったの に対して, アナターゼ型 $\mathrm{TiO}_{2}$ 担持白金触媒では $200{ }^{\circ} \mathrm{C}$ 付近で $\mathrm{CO}-\mathrm{H}_{2} \mathrm{O}$ 反応の $\mathrm{CO}_{2}$ 転化率の方が高くなり, $\mathrm{TiO}_{2}$ 結晶構造の違
いによって反応性に差が生じることが分かった。触媒表面の 化学的および物理的特性が活性に与える影響を明らかにするた めに種々のキャラクタリゼーションを行った。 $\mathrm{CO}_{2}$ - TPD 測定 により, $\mathrm{NO}-\mathrm{CO}-\mathrm{H}_{2} \mathrm{O}$ 反応中に形成された $\mathrm{CO}_{2}$ が活性に影響が ないことが明らかになった。DRIFTS 測定によって, NO-CO$\mathrm{H}_{2} \mathrm{O}$ 反応下で触媒に吸着した formate 種およびアンモニア種を 確認した。特に formate 種はアナターゼ上でのみ $200{ }^{\circ} \mathrm{C}$ で消失 することを確認し, formate 種の生成と $\mathrm{NH}_{3}$ 生成には関連があ ることが示唆された。以上の結果から, $\mathrm{TiO}_{2}$ 表面上で形成され る formate 種の生成が $\mathrm{NO}-\mathrm{CO}-\mathrm{H}_{2} \mathrm{O}$ 反応における $\mathrm{NH}_{3}$ 生成に影 響を及ぼすと考察した。 